to Messrs. G. Howard Humphreys (London) and I. M. E. Aitken (British Guiana); a Telford premium jointly to Messrs. A. D. Butcher (Egypt) and J. D. Atkinson (Egypt); a Telford premium jointly to Messrs. R. V. Allin (Essex) and Maurice Nachshen (London); a Telford premium jointly to Prof. A. H. Gibson (Manchester) and Mr. William Cowen (Manchester); Telford premiums to Messrs. H. C. E. Cherry (Rangoon, Burma), F. W. Furkert (Wellington, N.Z.), and H. A. Lewis-Dale (London); a Crampton prize to Mr. C. M. Norrie (London). For papers published without discussion as 'selected engineering papers' : A Telford premium to Mr. A. C. Vivian (London); a Telford premium jointly to Messrs. R. D. Duncan (Belfast) and E. M. R. Jones (London); a Telford premium jointly to Mr. J. S. Lavery (Oxford) and Prof. R. V. Southwell (Oxford); Telford premiums to Messrs. Alfred Bailey (London), J. B. M. Hay (Ilkley), Harris Booth (London), L. R. East (Victoria, Australia), and C. G. Watson (London). For papers read by students: The James Forrest medal and a Miller prize to Mr. I. C. Easton (Glasgow); the James Prescott Joule medal and a Miller prize to Mr. Norman Parry (Newcastie upon Tyne); Miller prizes to Messrs. J. A. Fisher (London), Herbert Bruce (Glasgow), C. M. Roberts (Glasgow), F. B. S. Grimston (London), J. S. Williams (London), P. W. E. Holloway (London), A. C. Buck (London), and W. M. Ogden (Manchester).

\section{Index to the Mathematical Gazette}

We have received an Index to Vols. 1-15, 1894-1931, of the Mathematical Gazette. Since the late Mr. W. J. Greenstreet was editor from the later numbers of Vol. 1 to the earlier numbers of Vol. 15, the index is in effect a monument to his life's work. It is an elaborate volume of xii +164 pages, produced with great care. Of the most important sections, one lists about 600 articles, one about 1,000 notes, and one about 1,800 reviews. The last shows the standing of the Gazette with mathematical publishers at home and abroad, and the wealth of expert criticism which it secures for its readers. There is no attempt at a subject classification of articles or notes, but where a title is uninform. ative, the compilers have inserted a brief indication of the contents; they have also given cross-references, and by an occasional sly extract added a touch of humour to their matter-of-fact pages. Although complete sets of the Gazette are scarce, the publishers (Messrs. G. Bell and Sons, Ltd.) and the Mathematical Association hold a considerable stock of individual numbers, and anyone whose interest is aroused by entries in this fascinating index will probably be able to satisfy his curiosity.

\section{Patent Procedure}

UNDER the title "Practical Hints on the Patenting and the Development of Inventions" an interesting and useful booklet has been issued by the Imperial Patent Service, First Avenue House, High Holborn, London, W.C.l. The principal of the Service is Mr. M. E. J. Gheury de Bray, author of books on hyperbolics and exponentials, and of a number of papers on astronomical and engineering subjects, including contributions to these columns upon possible secular changes in the velocity of light. The work of the Service is distributed between three sections dealing respectively with research, patents, and economics or development. The second edition of the pamphlet just published affords helpful guidance respecting patent procedure, and also information on trade marks, designs and copyright.

\section{Environment and Race}

IN "An Atlas of Environment and Race" (University of Chicago Bookshop, 40 cents), which is issued to accompany a course of lectures broadcast from Chicago by Prof. Griffith Taylor, is a series of 110 maps, of which 65 have not previously been published. The series, in addition to the maps of racial distribution usually accompanying the discussion of this topic, covers matters such as land elevation, elimatic variation, vegetation, stratigraphical evidence and cultural distributions. As a whole, the series is both original and stimulating. The course is designed to prove the 'zones and strata' theory, in which, adopting the criteria of skull form and hair character, it is argued that the races of the world are arranged in five zones about central Asiaa theory already advanced by Prof. Taylor in his "Environment and Race" (1927). Prof. Taylor stresses the paramount importance of the study of race to-day on the ground that two thirds of the world is occupied by coloured peoples "often chafing under European domination".

\section{New Sunspot Cycle}

A MEssage from the New York correspondent of the Times, published in the issue of November 4, announces that the beginning of a new sunspot cycle is reported at Mount Wilson. At the present time, sunspot activity is at a minimum, and it would be difficult to ascertain definitely the beginning of the new cycle, which might be masked by a minor fluctuation, but for the fact that the spots in a new cycle tend to occur in high latitudes (as shown by the well known 'butterfly' diagram), and, more definite still, the magnetic polarity of the spots changes alternately in successive cycles. The Greenwich records show a small pair of spots in a moderately high latitude $\left(30^{\circ}\right)$, and presumably the Mount Wilson observers have determined its polarity and found it to be that of the new cycle. That the new sunspot maximum will bring a maximum of disturbance to the earth's magnetic field is well established, but the correlation with other phenomena is less certain.

\section{Announcements}

Dr. Herbert Levinstein will deliver the fifth S. M. Gluckstein memorial lecture before the Institute of Chemistry on Friday, December 15, at 8 p.m. The subject of Dr. Levinstein's lecture will be "The Chemist as a Directing Force in Industry".

Mr. Wharton Huber, associate curator of birds and mammals in the Academy of Natural Sciences of Philadelphia, has returned from a six months' 